This is the version of an article accepted for publication in Theory Culture and Society published by Sage: http://tcs.sagepub.com/

Accepted version downloaded from SOAS Research Online: http://eprints.soas.ac.uk/23092/

\title{
Elite Business Networks and the Field of Power: A Matter of Class?
}

\author{
Mairi Maclean, University of Bath \\ Charles Harvey, Newcastle University \\ Gerhard Kling, SOAS University of London
}

\begin{abstract}
We explore the meaning and implications of Bourdieu's construct of the field of power and integrate it into a wider conception of the formation and functioning of elites at the highest level in society. Corporate leaders active within the field of power hold prominent roles in numerous organizations, constituting an 'elite of elites', whose networks integrate powerful participants from different fields. As 'bridging actors', they form coalitions to determine institutional settlements and societal resource flows. We ask how some corporate actors (minority) become hyper-agents, those actors who 'make things happen', while others (majority) remain 'ordinary' members of the elite. Three hypotheses are developed and tested using extensive data on the French business elite. Social class emerges as persistently important, challenging the myth of meritocratic inclusion. Our primary contribution to Bourdieusian scholarship lies in our analysis of hyper-agents, revealing the debts these dominants owe to elite schools and privileged classes.
\end{abstract}

\section{Keywords}

Bourdieu, elite careers, field of power, French corporate elite, hyper-agency, network analysis, social class, social mobility

The formation and exploitation of social networks are fundamental to leadership within the modern corporate economy (Burt, 1992; Kerr and Robinson, 2011;

McDonald et al., 2008; Useem, 1984). This paper employs network analysis and multivariate models to explore the determinants of access to and membership of the corporate 'elite of elites' in France, whose networks and career trajectories we track over a six-year period. It draws on Bourdieu's (1993: 37-39; 1996a: 264-272) concept of the 'field of power', the integrative social domain that transcends individual fields and organizations, serving as a metafield of contestation for dominant agents from different backgrounds. We scrutinise the differentiating features of those actors whose networks enable them to transcend individual fields, either by bridging corporate 
This is the version of an article accepted for publication in Theory Culture and Society published by Sage: http://tcs.sagepub.com/

Accepted version downloaded from SOAS Research Online: http://eprints.soas.ac.uk/23092/

networks or by engaging in extra-corporate networks. Our study is therefore concerned with the educational trajectories, class origins and other salient social features (such as gender) of main board directors of France's leading companies, as well as the social characteristics of those who make up the most interrelated networks (corporate and non-corporate) within the field of power, thus appearing as 'hyperagents'.

Actors with the strongest networks and most refined networking capabilities most often are those at the pinnacle of the largest business enterprises (Carroll and Sapinski, 2011; Mizruchi, 1986). The most powerful of all - hyper-agents, the elite within the elite - are invited to sit on the boards of other large companies and prestigious non-profit organizations, multiplying the number and range of their personal connections (Geletkanycz and Hambrick, 1997). These hyper-agents act as 'bridging actors', seeking through the formation of coalitions to determine institutional settlements and control societal resource flows. We suggest that hyperagency represents a key means whereby an elite-dominated field of power is developed and sustained. While it is sometimes implied that business leaders are more fragmented and less influential than other elites (Hermskerk, 2007), this article adopts a different perspective, focusing on the networking capabilities of the French business elite to identify how the most powerful attain their positions as hyper-agents (Coignard and Guichard, 2000). Hence, we take what might at first glance seem a relatively familiar research method and interpretive framework - network analysis and interlocking directorships - and extend and complicate these by drawing on Bourdieu's (1986, 1993, 1996a) concepts of field, field of power and forms of capital. Adopting Bourdieu's theoretical framework as a lens through which to explore corporate elites illuminates the 'bridging actors' that link disparate elite sectors. There 
This is the version of an article accepted for publication in Theory Culture and Society published by Sage: http://tcs.sagepub.com/

Accepted version downloaded from SOAS Research Online: http://eprints.soas.ac.uk/23092/

are, of course, unique aspects to the French business system, limiting the generalizability of our findings. Equally, the processes determining the composition and functioning of the field of power in France are likely nevertheless to be similar to those in other Western economies, lending more general theoretical significance to our research (Burt et al., 2000; Useem and Karabel, 1986).

There is, with notable exceptions (Courpasson and Clegg, 2006; Kling et al., 2016; Maclean et al., 2010, 2014; 2015; Reed, 2012; Zald and Lounsbury, 2010), relatively little research on how those emerging as hyper-agents create extensive social networks within and beyond the corporate sphere. Even less has been written about the ways in which business elites compete and co-operate with elites from other domains within the field of power (Mills, 1956; Savage and Williams, 2008; Useem, 1984). This is regrettable given the disproportionate exercise of power by the few, and the social struggles that inform stratification. In particular, the role played by social class in networking and elite reproduction has been neglected (Dezalay, 1995; Scott, 2002), precluding a fuller understanding of how power is acquired and applied at the highest level (Denord et al., 2011).

It is this gap in the literature that the present article addresses. Our aim is to explain the processes of differentiation by which small numbers of elite corporate actors become hyper-agents and bridging actors while a majority does not, examining what sets them apart. We apply network analysis and multivariate models to an extensive dataset profiling the lives and careers of 1159 leaders at the top of the French corporate hierarchy. Our study identifies direct and indirect relationships between critical variables, rigorously testing the three hypotheses we advance. In the following section, we elaborate Bourdieu's concept of the field of power in terms of purpose, social networks and domination by hyper-agents. Next, we develop three 
This is the version of an article accepted for publication in Theory Culture and Society published by Sage: http://tcs.sagepub.com/

Accepted version downloaded from SOAS Research Online: http://eprints.soas.ac.uk/23092/

hypotheses around which the paper is framed. Our methodology is then detailed followed by the presentation of our main findings, laying the foundations for further theorization and reflection in our discussion and conclusion.

\section{Networks and the Field of Power}

Bourdieu's master theories of capital, field and habitus have opened up fresh avenues for research in numerous disciplines within the social sciences (Wacquant, 2002). His construct of the field of power, conversely, has received relatively little attention despite its novelty and theoretical potential (Bourdieu, 1993, 1996a, 2011; Denord et al., 2011; Swartz, 1997, 2008). The construct is essentially the 'capstone' of his theory of fields in which society is conceived as divided into a series of domains and sub-domains, each defined by prevailing field-specific rules of competition, practices and actor dispositions (Swartz, 1997). Fields are more or less stratified, with actors, corporate and non-corporate individuals, hierarchically differentiated by the amounts of capital (economic, social, cultural and symbolic) they possess (Anheier et al., 1995; Bourdieu, 1986a, 1990; Harvey and Maclean, 2008; Savage et al., 2005). The particular mix of capitals needed to progress upwards varies by field. Dominant actors possess the capital needed to influence the rules of the game and accumulate power. Subordinate actors have less capital and hence less power. To compete and advance they must innovate and pursue clever strategies to undermine the power and legitimacy of more established actors. The odds are stacked against them, but it remains possible in most domains for some to progress and join the field elite (Bourdieu 1986, 1990). Within business, for example, this means rising to become a leader (owner or top executive) within a large corporation. Within politics it means assuming a ministerial position and within public administration it implies joining the upper echelons of government service (Dudouet and Joly, 2010; Genieys, 2005). 
This is the version of an article accepted for publication in Theory Culture and Society published by Sage: http://tcs.sagepub.com/

Accepted version downloaded from SOAS Research Online: http://eprints.soas.ac.uk/23092/

There are counterparts in all fields, but all fields are not equal. In France, the corporate, political, administrative and financial elites form the core of the ruling elite, which nonetheless interacts routinely with members of the media, cultural, intellectual and scientific elites (Maclean et al., 2006; Suleiman, 1978). The field of power thus embraces members from a multiplicity of fields, but with some fields far more heavily represented than others (Wacquant, 1993). It might be thought of as an affiliation of dominant agents transcending individual fields. Only a minority of members of field elites accede to the field of power as bridging actors, effectively sitting above individual field elites which they transcend. The construct of the field of power effectively shifts the emphasis away from the hierarchical distribution of power to the inter-organizational, where dominant agents compete and collaborate variously with peers across different life-worlds (Zaheer et al., 2010).

The field of power functions as a 'macro-level arena of struggle' (Swartz 2008: 50) concerned with change or resistance to change It both sets elite agents against one another, whilst providing the necessary structural conditions for them to collaborate through the formation of time-limited, issue-based coalitions (O'Mahony and Bechky, 2008). Through networks forged within the field of power, elite agents seek to influence societal decision-making processes, resource flows, opinion formation and wider logics of action by strengthening commitment to particular projects or objectives or to the status quo. They 'make accounts', as Giddens (1984: 29) writes, becoming the purveyors of legitimizing narratives designed to inform collective systems of meaning (Creed et al., 2002; Lindsay, 2008; Lounsbury and Glynn 2001). Fligstein (1997) explains how they exploit their social skills to direct authority and frame action. It is essential that their actions are legitimized by wider public perceptions of civic-mindedness and disinterestedness (Bourdieu 1996a: 389; 
This is the version of an article accepted for publication in Theory Culture and Society published by Sage: http://tcs.sagepub.com/

Accepted version downloaded from SOAS Research Online: http://eprints.soas.ac.uk/23092/

Harvey et al., 2011), since, as Fligstein (1997: 400) argues, 'if others think that one wants something and that it is narrowly for selfish purposes, then they are unlikely to try to negotiate'. Hence, a number of activities on the part of hyper-agents are disinterested, even if agents have interests in such disinterestedness (e.g. sitting on the boards of museums, churches etc.).

Accession to the field of power is arduous and cannot be taken for granted. In France, prior research suggests that broadly defined about a third of elite directors enter the field of power (Maclean et al., 2014). Membership of what Mills (1956: 281) dubs the 'fraternity of the successful' depends on becoming a bridging actor connecting distinct networks. Here we propose that the best strategy for entering and maintaining position within the field of power is to seek appointment to the boards of both large corporations and prestigious non-profit organizations in the public, educational, cultural, sporting and charitable sectors (Westphal and Zajac, 1995; Zajac and Westphal, 1996). Board memberships, corporate and extra-corporate, are prized not just for the immediate rewards they confer - financial and symbolic in the corporate sector and symbolic in the non-profit sector - but also for the high-level connections they bring. Boards are meeting-places and membership creates the bonds of affiliation (social capital) needed to operate effectively within the field of power (Stern and Westphal, 2010; Stevenson and Radin, 2009). Membership of non-profit boards is especially important in this aspect, affording access to actors from different life-worlds, which is needed to form coalitions to pursue or resist changes in opinions, laws and regulations (Harvey et al., 2011). Lindsay (2008: 62) calls this 'convening power', one of the most compelling resources at the disposal of elites.

How, then, do elite corporate actors become differentiated, a minority becoming hyper-agents active within the field of power? The French corporate 
This is the version of an article accepted for publication in Theory Culture and Society published by Sage: http://tcs.sagepub.com/

Accepted version downloaded from SOAS Research Online: http://eprints.soas.ac.uk/23092/

economy is generally portrayed as unified, characterized by dense, cohesive networks and the closeness of relations between the state and corporate sectors (Dudouet and Joly, 2010; Kadushin, 1995; Maclean et al., 2007). As Hall (2008) emphasizes, however, France has worked hard to meet the challenges of the new global economy. Since the late 1990s, the French economy has undergone considerable change, due largely to the growing presence of foreign, mainly US, institutional investors in the share capital of French firms (Hancké, 2002; Maclean, 2002). In Morin’s (2000: 37) view, the country has moved from being a financial network economy to being a financial market economy, "directly inspired by the American "shareholder value" model', with foreign institutional investors playing a significant role in the French stock market. Institutional investors have been attracted both by the relative withdrawal of the French state, as the country receded from being a 'statist political economy', and by the concomitant introduction of governance measures associated with the Anglo-American model (Culpepper, 2008: 29; Goyer and Jung, 2011). In parallel, the cross-shareholdings which once formed the bedrock of French corporate capitalism have unraveled significantly. Financialization has not helped growing inequalities which, despite longstanding values of liberty, equality and fraternity, are pronounced and intensifying (Godechot, 2011; Piketty, 2014).

According to Eymeri (2001: 824), agents in senior positions retain similar 'ways of seeing, feeling, thinking and acting' stemming in part from the 'strong and homogenous bureaucratic training' imparted by the grandes écoles (Genieys, 2005: 419). Subsequent admission to a grand corps - like the Inspection des Finances, the Corps des Mines or the Corps des Ponts et Chaussées, the pinnacle of France's civil service elite, accession to which depends on the rank obtained in the final examinations - followed perhaps by time spent in a Ministerial Cabinet, literally 
This is the version of an article accepted for publication in Theory Culture and Society published by Sage: http://tcs.sagepub.com/

Accepted version downloaded from SOAS Research Online: http://eprints.soas.ac.uk/23092/

fosters an esprit de corps (Suleiman, 1978). Bourdieu and Passeron (1977) conceive of the French educational system as retrogressive because access to the best institutions is dominated by the upper classes, ultimately strengthening disparities in culture, status and wealth. Turning economic capital into meritocratic performance legitimates access to elite positions both in the eyes of those possessing the education and those who might be expected to challenge inheritance (Khan, 2011). The outward appearance of equal opportunity is sustained by the notion of a 'meritocratic society which rewards effort and ... selects the best' (Pinçon and Pinçon-Charlot, 2007: 103). The grandes écoles foster 'the belief of the dominant class in their own legitimacy and ... the belief of the other classes in that legitimacy' (Wacquant, 1993: 39). Of the 1048 business leaders out of our sample of 1159 for whom we have HE data, 52\% attended a top ten elite establishment, with the Ecole Polytechnique, the Institut d'Études Politiques de Paris (IEP), the Ecole Nationale d'Administration (ENA) and HEC Paris the most popular. Hence we propose:

Hypothesis 1: Having an elite education is a source of continuing advantage in establishing elite corporate connections.

The literature on social networks emphasizes the value of bridge-building in bolstering power (Coignard and Guichard, 2000; Collins-Dogrul, 2012; Geletkanycz and Hambrick, 1997). The external activities of directors advance careers and increase rewards (Useem, 1984). Burt et al. (2000: 141) found that successful French executives benefited from networks rich in 'structural holes', rewards accruing 'disproportionately to people who provide indirect connections between otherwise disconnected groups'. We know much less about the advantages of bridging between corporate and non-profit (charitable or voluntary) organizations (Stern and Westphal, 
This is the version of an article accepted for publication in Theory Culture and Society published by Sage: http://tcs.sagepub.com/

Accepted version downloaded from SOAS Research Online: http://eprints.soas.ac.uk/23092/

2010), but reason that increasing network diversity should de facto increase an agent's chance of attaining top-tier corporate positions. Hence we propose:

Hypothesis 2: Extra-corporate networking beyond the business sphere serves to enhance business networks, increasing the size and strength of an agent's elite corporate network.

Palmer and Barber (2001) argue that embeddedness in prized networks is a manifestation of the class system, implying that corporate agents who suffer social status marginality have greater difficulty in penetrating the 'inner group' active in the field of power. Westphal and Zajac (1995) stress the importance of demographic similarity in director selection. For Stern and Westphal (2010), the agents best equipped to secure board appointments engage in ingratiating behaviour that enhances interpersonal appeal. These behaviours are more common amongst those from upperclass backgrounds. For Bourdieu (1986: 101), life chances are objectively inscribed in the volume and composition of an individual's capital. Social class is internalized as 'class habitus', conditioning behaviour and influencing life chances. The material effect of social class on an agent's 'trajectory in social space', in terms of career progression and durability in the field of power, is likely far-reaching (Bourdieu, 1987: 4). Hence we propose:

Hypothesis 3: Social class serves a master variable underpinning an agent's potential for corporate networking and hyper-agency, enhancing the likelihood of becoming a bridging actor.

Our study is based upon personal and career profiles of 1159 members of the French corporate elite: those serving as main board members, executives and nonexecutives, of one or more of France's top 100 largest companies in January 1998. 
This is the version of an article accepted for publication in Theory Culture and Society published by Sage: http://tcs.sagepub.com/

Accepted version downloaded from SOAS Research Online: http://eprints.soas.ac.uk/23092/

The top 100 French companies were identified by computing an equally-weighted composite measure of size based on total capital employed, turnover, profit-beforetax, and the number of employees. Individual level data were gathered from five main sources: company annual reports; Le Guide des Etats Majors; Who's Who in France; extensive web searches, including company websites, Business Week, Forbes and the Financial Times; newspaper and periodical articles. We collected data on age, gender, place of upbringing, social origins, career, education, honours, personal interests, and corporate and extra-corporate networks for all members of the elite, focusing on their career trajectories over a six-year period between 1998 and 2004. This was an eventful period for France, marked by deepening European integration, the advent of the single currency, increasing foreign ownership of the equity of top French firms (as mentioned), and continuing corporate governance initiatives (driven by Marc Viénot and Senator Philippe Marini in particular) leading to the implementation of the Nouvelles Régulations Economiques and the 2003 loi de sécurité financière.

Bourdieu combined qualitative and quantitative analysis (through his multiple correspondence analysis) in his research, believing that this exploits the linkage between theory and research to best effect (Bourdieu, 1987; Robson and Sanders, 2009). While we focus here on multivariate analysis, we complement this elsewhere with qualitative analysis of social mobility drawing on interview data (Maclean et al., 2012), which Bourdieu (1996b: 17) favoured as a means of capturing 'the almost infinitely subtle strategies that social agents deploy in the ordinary conduct of their existence'.

\section{Research Process}


This is the version of an article accepted for publication in Theory Culture and Society published by Sage: http://tcs.sagepub.com/

Accepted version downloaded from SOAS Research Online: http://eprints.soas.ac.uk/23092/

Following Halsey (1995), a four-way classification was adopted for social class: upper, upper-middle, lower-middle, and lower class. We favoured this over the threeway class hierarchy provided in Bourdieu's (1986: 526) Distinction (working, middle and upper classes), because it compelled us to specify whether middle-class actors were upper- or lower-middle class. The starting-point of our categorization is parental occupation, which we used for the purposes of classification according to the following schema (Bourdieu, 1987; Denord et al., 2011). Upper class (C_1) was reserved for those whose parents held a leading position in society or owned sizeable $(\geq 1 \%)$ equity stakes in top French companies. Upper-middle class (C_2) was applied to top professionals including lawyers, doctors, engineers, senior state officials, and senior business people. Lower-middle class (C_3) was applied to white-collar occupations including teachers, sales people, lesser officials and technicians; while lower class (C_4) was reserved for parental occupations like worker, miner and van driver. Educational data were coded by attendance (or not) at an elite school (ES) and attendance (or not) at one or more elite HE institution (EHE). Bourdieu (1996a: 7475) defines elite schools as 'institutions entrusted with the education and consecration of those who are called to enter the field of power', such as 'the top Paris lycées, Louis-le-Grand, Henri-IV, and Fénelon'; the top non-Parisian school attended by our sample being the Lycée du Parc in Lyon. Top 100 company main board memberships were recorded for 1998 and 2004, but subsidiary board memberships were excluded. The type and extent of engagement in non-profit networks was recorded, covering charities, public bodies, industry association, HE, sports and culture. Overall network reach for individuals is captured by the total number of corporate and extra-corporate board memberships. The number of life-worlds spanned by an individual is a count of the types of boards they served on between 1998 and 2004 . 
This is the version of an article accepted for publication in Theory Culture and Society published by Sage: http://tcs.sagepub.com/

Accepted version downloaded from SOAS Research Online: http://eprints.soas.ac.uk/23092/

We seek to explain variations in the size and strength of the corporate networks of members of the French business elite. As a first step, our dataset was converted into a relational matrix making corporate ties (undirected relations) the unit of observation. From 1159 elite members we derived 11946 ties, a mean score of 10.3 per member of the corporate elite. The number of ties between actors would be increased considerably if non-corporate board memberships (i.e. beyond the corporate sphere) were included. Exploring ties in external networks is more challenging due to lack of information (i.e. only major roles are disclosed) and the high degree of diversity in terms of position. Both issues cause conceptual problems as ties should be defined consistently, ideally formed by similar actions or positions. Accordingly, we only focus on the number of external networks (EXNET), measuring the scale of networks outside the business sphere. Consistent with our hypotheses, we identified 'bridging actors' who connect two or more corporate networks, as illustrated in Figure 1. The powerful actor (429) depicted here connects the otherwise isolated network formed by the directors of Dassault Systèmes to other corporate networks in France.

\section{[FIGURE 1 HERE]}

There are various ways of measuring the relative strength of an individual's position within a social network (Borgatti et al., 2009). Here we apply an eigenvector centrality measure, which is commonly applied in the literature. Ties to other actors are assessed based on their weight in the network: a tie to an actor who is well connected counting more than a tie to an isolated actor; all ties being measured using eigenvector centrality. We also count the number of ties per actor then order our data in two dimensions: quantity of connections and quality of connections based on eigenvector centrality. In this way, the data contained in the relational matrix is reintegrated into our standard cross-sectional dataset with individuals as the unit of 
This is the version of an article accepted for publication in Theory Culture and Society published by Sage: http://tcs.sagepub.com/

Accepted version downloaded from SOAS Research Online: http://eprints.soas.ac.uk/23092/

observation. This enables us to identify using multivariate models the factors determining the size and strength of corporate networks.

Table 1 reports summary statistics for the whole sample. Membership is homogenous in predicable aspects: 95\% are men and 94\% are French. Since 2004, the presence of women director on leading French boards has increased (Moulin, 2013). However, the French business elite has not experienced the degree of internationalization one might expect. Preferencing those who have attended a grande école, are members of a grand corps and may have served in a Ministerial Cabinet militates against the recruitment of foreigners to top positions (Hartmann, 2011). Companies whose boards were especially internationalized boards included Dexia, $60 \%$ of whose members were non-French, followed by Alstom (56\%), Orange, Suez and Aventis (50\%); reflecting their origins, involvement in mergers, and the correspondingly high percentage of company turnover achieved abroad (Korn/Ferry International, 2002; Harvey and Maclean, 2010). In terms of social class, those originating from social classes one and two dominate (63\%). Just $21 \%$ of the elite are bridging actors connecting two or more corporate networks. These are the hyperagents who dominate the field of power in France. The remaining $79 \%$ is composed of 'ordinary' members who presently do not bridge corporations, although they may have extra-corporate networks and might in the future emerge as bridging actors.

\section{[TABLE 1 HERE]}

In panel A of Table 2 we can see that bridging actors often come from the top two social classes; for example, $69 \%$ of bridging actors had the advantage of elite schooling compared to $52 \%$ of ordinary actors. There is an evident class divide. Just $5 \%$ of all members of the elite emerged from the lowest social class, and the divide becomes yet more pronounced with respect to bridging actors. We might surmise that 
This is the version of an article accepted for publication in Theory Culture and Society published by Sage: http://tcs.sagepub.com/

Accepted version downloaded from SOAS Research Online: http://eprints.soas.ac.uk/23092/

having an elite education and coming from a high-status background are positively related to access to corporate and non-profit organizations. This is confirmed in Panel $\mathrm{B}$, which shows that a high proportion of individuals from the upper classes span three or more life-worlds. Panel C likewise confirms that extra-corporate networks are the domain of the top two social classes.

\section{[TABLE 2 HERE]}

The statistics presented in Table 1 are suggestive rather than conclusive. Some variables are related, implying the co-existence of both direct and indirect causal effects. For example, social class might be causal with respect to elite education. For individuals from the top two classes an elite education is almost a given: $83 \%$ being educated at an elite school and $75 \%$ having an elite higher education, whereas just $22 \%$ of individuals from the lower-middle class and $18 \%$ from lowest class attended an elite school. Matters of causality, direct and indirect, are explored in the multivariate analysis that follows.

The size of individual corporate networks varies widely from one to 77 direct ties. Measures of network strength (ST) based on average eigenvector centrality and maximum eigenvector centrality (MAX_ST) exhibit similar degrees of heterogeneity. As most individuals achieve an eigenvector centrality of zero, indicating weak networks, we use tobit models for the left-censored dependent variables ST and MAX_ST. Additionally, we report a logit model where the dependent variable STRONG assumes the value one if an individual has a strictly positive eigenvector centrality, or zero otherwise.

Based on our hypotheses, we test whether (1) elite education, (2) extracorporate networks, and (3) social class, affect the size and strength of corporate networks. We include the following independent variables: GENDER (coded one for 
This is the version of an article accepted for publication in Theory Culture and Society published by Sage: http://tcs.sagepub.com/

Accepted version downloaded from SOAS Research Online: http://eprints.soas.ac.uk/23092/

males and zero for females), AGE in years, and dummy variables for French nationality (NATION), being raised in the Paris region (PARIS), attending an elite school (ES), and attending an elite HE establishment (EHE). To test whether networks outside the business sphere are of causal significance, we include the number of external ties (EXNET). Bridging actors who connect two or more networks are identified using the dummy variable BRIDGE. Finally, we incorporate dummy variables for each social class, using the lowest (C_4) as reference category.

In Table 3, column A references the dependent variable SIZE, columns B and C respectively report on tobit models used to explain MAX_ST and ST of individual networks, and column D references the logistic model with the dummy variable STRONG as the dependent variable. The findings reported in column A confirm that being a bridging actor enhances network size, and that enjoying an elite education (ES, EHE) and having extra-corporate networks have a positive bearing on network size. From columns $\mathrm{B}$ and $\mathrm{C}$, there is confirmation that being a bridging agent enhances network strength, but this is not the case for specification D. For models B and $\mathrm{C}$, being raised in the Paris region strengthens corporate networks. However, the supposition that class has a positive bearing on network size is not supported.

Together these findings confirm that bridging actors hold strong positions in corporate networks, that having an elite HE helps in forming large networks, and that having extra-corporate networks boosts the size of corporate networks.

\section{[TABLE 3 HERE]}

The most surprising results are those relating to social class, which appears to have little bearing on the formation of corporate networks. This, however, would be a false conclusion because class does not bear directly on outcomes, but operates indirectly through its impact on educational opportunities and networking capabilities. 
This is the version of an article accepted for publication in Theory Culture and Society published by Sage: http://tcs.sagepub.com/

Accepted version downloaded from SOAS Research Online: http://eprints.soas.ac.uk/23092/

In Table 4, we report the findings of five additional models that demonstrate the indirect effect of class on corporate networking. Column E references an OLS regression explaining the size of extra-corporate networks. This highlights the importance of age, confirming that elite corporate actors attract more invitations to join non-profit boards as their careers progress. It also confirms that individuals from the lower classes are disadvantaged relative to their upper- and upper-middle-class peers. In columns F and G, we model elite schooling and elite HE respectively using logistic regressions. These confirm the educational advantage conferred by being raised in and around Paris and the critical importance of social class in accessing elite educational institutions. Column $\mathrm{H}$ reports the results of a logistic regression with BRIDGE as the dependent variable. Here, the top social class does not have an indirect effect on outcomes; however, being in the upper-middle class has a positive impact on becoming a bridging actor. Once we control for elite education (Model I), the impact of being in the upper-middle class disappears suggesting indirect effects working through elite education. Emergence as a bridging actor linking otherwise unrelated networks can be seen as a strategy adopted by corporate elites independent of their social background. Nonetheless, our findings confirm that social class has a powerful indirect effect on the formation of corporate networks by way of ties forged through attendance at elite HE institutions and appointment to non-profit boards.

\section{[TABLE 4 HERE]}

Our findings confirm that having an elite higher education is directly beneficial to the formation of strong, extensive corporate networks. This is an unsurprising result consistent with Bourdieu's (1993, 1996a) theoretical stance and prior empirical studies (Hartmann, 2000; Suleiman, 1978; Useem and Karabel, 1986). Our findings also confirm that building networks outside the corporate sphere is a 
This is the version of an article accepted for publication in Theory Culture and Society published by Sage: http://tcs.sagepub.com/

Accepted version downloaded from SOAS Research Online: http://eprints.soas.ac.uk/23092/

source of networking advantage within it. Again, this is consistent with prior literature (Collins-Dogrul, 2012; Geletkanycz and Hambrick, 1997; Scott, 1991).

Our most important findings relate to the enduring importance of class in an ostensibly meritocratic society. We show how social class impacts significantly on access to an elite education and on the development of extra-corporate networks, both having a crucial bearing on corporate network formation. These findings are consistent with the work of Useem and Karabel (1986) on the US, but go further in implicating the relationship between class and extra-corporate networks in corporate network formation and the operation of the field of power.

\section{Discussion and Conclusion}

In an interview with Loïc Wacquant (1993) published in this journal, Bourdieu elaborates his thinking on the relationship between different modes of reproduction in society. He points to the structural homology between the French grandes écoles and the field of power, 'covering the whole set of dominant positions: the Episcopate, the university, employers, high civil service etc.' (Wacquant, 1993: 20). The construct of the field of power is presented as 'marking a break with all existing theories of the dominant', which are flawed because they study 'populations of agents' rather than 'structures of power' or the 'space of positions' occupied by agents in society (pp.2021). The proper object of analysis should be 'the objective relations that obtain between these various sub-spaces and the mechanisms which ... perpetuate the structures' (p.21). The research presented here has been conducted in this spirit, seeking to test and refine Bourdieu's original ideas while extending and building upon them, empirically and theoretically.

First, we contribute to research which conceptualizes processes of hierarchy and internal differentiation within elite groups (Flemmen, 2012). Critical here is the 
This is the version of an article accepted for publication in Theory Culture and Society published by Sage: http://tcs.sagepub.com/

Accepted version downloaded from SOAS Research Online: http://eprints.soas.ac.uk/23092/

distinction we draw between a majority of corporate leaders whose careers focus on the business domain and a powerful minority who assume a society-wide role, transcending the business field (Denord et al., 2011; Reed, 2012), demonstrating the on-going significance of the social class effect in the selection of hyper-agents. One of Bourdieu's most compelling insights is to demonstrate in a subtle, non-deterministic fashion how existing elites use a highly stratified education system as a mode of reproduction that confers upon their offspring dual legitimacy of 'the aristocratism of birth and the meritocratism of academic success' (Wacquant, 1993: 21). Education as an inter-generational mode of transmission of power exposes the upper classes to risk: success cannot be guaranteed as entrants from all social classes compete for academic distinction. However, for those who do make it, the prize is that of meritocratic legitimacy deriving from the symbolic power of elite academic honours. The uppermiddle classes (C_2) often do best in this regard, dominating the grandes écoles by combining birth and meritocracy to optimal effect. Our research provides tangible support for the continuing relevance of Bourdieu's ideas. While the correlation between social class and education is well known in the social sciences, being closely related to habitus, we demonstrate how this works practically in enhancing the chances of accession to the field of power. Education is shown directly to influence the capacity of business leaders to establish the corporate networks that are fundamental to hyper-agency and accession to the field of power. Educational socialization alone, conversely, is unlikely to culminate in hyper-agency without the additional impetus of social class. While compensatory for lower-class aspirants, the cultural capital acquired through education fails to compensate wholly, requiring a shared class-based habitus to operate to best effect (Hartmann, 2000). As Bourdieu (1990: 68) emphasizes, 'one cannot enter this magic circle by an instantaneous 
This is the version of an article accepted for publication in Theory Culture and Society published by Sage: http://tcs.sagepub.com/

Accepted version downloaded from SOAS Research Online: http://eprints.soas.ac.uk/23092/

decision of the will, but only by birth'. This challenges the notion that business elites have become more meritocratic, in that they are more 'self-made'. Hence, we add to earlier evidence that corporate wealth is not generally given to self-made men who have deferred gratifications and are endowed only by native talent; on the contrary, they have a high probability of having privileged education and origins within the upper or upper-middle classes. Our contribution to Bourdieusian scholarship lies most importantly in our analysis of hyper-agents - those actors who 'make things happen' within corporate elites and wider parts of the field of power, or alternatively offer resistance to change - which reveals the debts these dominants owe to elite schools and privileged classes.

Second, our research develops Bourdieu's analysis of social class effects (Bennett et al., 2009; Flemmen, 2012; Savage et al., 2005; 2015) by specifying a second mode of elite reproduction. In our models, the capacity of elite actors to establish extra-corporate networks by securing appointments to prestigious non-profit boards emerges as directly related to the establishment of corporate networks. By extending their social and organizational reach, agents increase the size and scope of their social networks and potential to operate effectively within the field of power, making them more attractive candidates for appointment to corporate boards (Zajac and Westphal, 1996). In this, bridging actors may supply the social glue which was previously provided by interlocking shareholdings, such that the French corporate economy retains its close cohesive character despite financialization and the advent of the euro (Morin, 2000). Again, as with access to elite education, social class operates indirectly to determine who wins and who loses in the networking game. Referencegroup dynamics are instrumental here (Bottero, 2004). Such agents benefit from the comforting shared resemblance or in-group bias which makes them attractive to their 
This is the version of an article accepted for publication in Theory Culture and Society published by Sage: http://tcs.sagepub.com/

Accepted version downloaded from SOAS Research Online: http://eprints.soas.ac.uk/23092/

peers, fostering mutual recognition (Ekman, 2013). For Bourdieu (1996a: 317), this is the guiding principle of upper-class groups, since such agents 'recognize themselves as members of the class, and in doing so, confer upon it the only form of existence a group can possess' (Bourdieu, 1987: 10).

In other words, high-status agents select one another, and are selected in turn, engendering in so doing a corporate class in its own right, such that higher social class is tacitly preferred if not directly required (Bourdieu, 1985, 1993). Mills (1956: 1389) concurs, arguing that 'in close-ups of the executive career, we observe how men in the same circles choose one another'. For Mills (1956: 141), accessing and engaging in the field of power is not a matter of ability, but one of replication through 'conformity with the criteria of those who have already succeeded'. The playingfields are not level or neutral but favour bridging actors distinguished by their higherstatus backgrounds and elite education, combining birth with meritocracy, who comprise the afore-mentioned 'fraternity of the successful'. In selecting fellow board members, agents recruit colleagues in their mirror image, whose conduct speaks of value similarity, with whom they can form lasting relationships (Stern and Westphal, 2010; Westphal and Zajac, 1995).

Third, building on Bourdieu's original conceptualization, our research highlights aspects of the nature and modus operandi of the field of power that hitherto have received scant attention in the literature. These relate to purpose, membership, habitus, networks and coalitions. As an integrative social domain at the pinnacle of society, the main purpose of the field of power is to reconstitute the institutional order in response to societal pressures driven upward through field hierarchies and wider social movements (Maclean and Harvey, 2016; Useem, 1984). This process of institutional adaptation is viewed by North (1990) as fundamental to economic and 
This is the version of an article accepted for publication in Theory Culture and Society published by Sage: http://tcs.sagepub.com/

Accepted version downloaded from SOAS Research Online: http://eprints.soas.ac.uk/23092/

social change, or to the preservation of the status quo. Membership of the power elite responsible for managing or resisting institutional change is, as we have seen, exclusive and dominated by those originating from the upper and upper-middle classes. For lower-class aspirants, class operates in a restrictive manner, curtailing ascent such that they often achieve 'next best' positions, failing to become hyperagents in their own right (Bourdieu, 1996a; Hartmann, 2000), excluded from ““forbidden” spaces of power' (Courpasson, Dany and Clegg, 2012: 811).

The field of power, of course, remains inaccessible to the great majority of people (Pinçon and Pinçon-Charlot, 2007). This is another reason why examining the determinants of access matters. It serves as a 'structuring structure' in its own right, through which members learn how to behave by absorption in a field of powerspecific habitus (Bourdieu, 1990: 53). Hyper-agents occupy a practical world of boards, networks, committees, colloquia and other meeting-places (e.g. the exclusive Club du Siècle, the epitome of privilege) that serve as normative instruments for the power elite of corporate capitalism (Giddens, 1984). The common objectified properties shared by top directors in the corporate field create a corporate-based social class, producing what Le Wita (1994: 18) calls an '[haute] bourgeoisie of work'. This class is organically unified by virtue of an 'incomparable plurality of principles of domination (power or type of capital), which limits competition between power holders and promotes partial and multiple alliances amongst them' (Bourdieu, 2011: 137), encompassing potentially adversarial interests within a shared worldview, such that elites - corporate, political, administrative and technocratic - are often remote from the rest of the populace. At a time when relations between the state and its citizens are purportedly being renegotiated (Jessop, 2007), when the success of the European project (recently called into question by the British Brexit vote of June 
This is the version of an article accepted for publication in Theory Culture and Society published by Sage: http://tcs.sagepub.com/

Accepted version downloaded from SOAS Research Online: http://eprints.soas.ac.uk/23092/

2016) has ceded numerous powers from Paris to Brussels (Genieys, 2005), elite preservation remains the order of the day.

The networks through which corporate members accomplish institutional change are extensive, spanning numerous life-worlds; prominent politicians, government officials, journalists, intellectuals, financiers and other 'structural equivalents' are subject to the convening power of those controlling massive economic capital (Lindsay, 2008). Networks are not hard-wired but reconfigure (and unravel) in pursuit of specific campaigns (Ahuja, 2000; Ahuja et al., 2012; Das and Teng, 2002). In this way coalitions of hyper-agents emanating from different fields are assembled, perhaps temporarily, united by a common goal. One coalition may be defeated by another in competitive contests to reframe ideas, policies, regulations and laws. At stake are outcomes of far-reaching significance for society-at-large (Zald and Lounsbury, 2010).

Is the field of power as depicted above distinctive to the French context by reason of specific historical trends and elite formations that have existed for some time? The long-standing 'exceptional' nature of the French business system (Genieys, 2005), characterized by the strength of the grandes écoles and their continuing centrality in business, finance, politics and public administration, might lead one to think so (Dudouet and Joly, 2010; Eymeri, 2001). There is also something of a 'Paris effect', given the extreme centralization of the French system - home to the best educational institutions, the key organs of government, the headquarters of most leading French companies, and the haute bourgeoisie in the stylish $16^{\text {th }}$ arrondissement. Bourdieu's findings are not universal but historically (and culturally) variable. This suggests that the field of power might actually best be conceived not as a single, abstract entity as it is commonly presented (Bourdieu, 1993: 1996a; 2011), 
This is the version of an article accepted for publication in Theory Culture and Society published by Sage: http://tcs.sagepub.com/

Accepted version downloaded from SOAS Research Online: http://eprints.soas.ac.uk/23092/

but rather as plural, variegated fields of power couched within different regimes and jurisdictions. This has implications for studying elites in other European countries, best situated within their particular socio-political and cultural habitus (Hartmann, 2000).

We have shown, in the case of France, that hyper-agency and inclusion within the power elite remains predominantly a matter of class. We shed light on the enduring advantage of higher-status backgrounds at a time when high income and wealth are attracting increasing attention (Boltanski and Chiapello, 2007; Piketty, 2014). We challenge researchers to reconsider class, which has been largely forgotten. Our findings run counter to current fashions concerning elites and power by demonstrating that the hyper-agent elite has a higher preponderance of higher class measures than the 'ordinary' business elite, in terms of education and other class factors. This is a challenge to recent literature which often suggests that conventional class measures have become less significant (Giddens, 1991; Savage, 2000) and that business elites have become more meritocratic, being 'self-made' (Khan, 2011). It may well be the case, as Bennett et al. (2009: 1) observe, that 'the vocabularies of class have lost much of their purchase in both public and political life', but this does not mean that class has ceased materially to influence career trajectories and allocative outcomes. Our findings show that socially reproductive forces remain powerful in deciding who rules in the 'magic circle' at the highest level in society. In the present state of inequalities, resistance to change from incumbents who benefit from existing arrangements can be powerful (Boltanski and Chiapello, 2007). Although as we have argued, this should not be taken to imply that social conservatism necessarily prevails. As Hall (1984: 283) insists, the political dimensions of economic management are not set in tablets of stone and from time to 
This is the version of an article accepted for publication in Theory Culture and Society published by Sage: http://tcs.sagepub.com/

Accepted version downloaded from SOAS Research Online: http://eprints.soas.ac.uk/23092/

time may be recast; as the advent of the euro, the growing significance of Europe and the spread of financialization in France have demonstrated. The field of power by its very nature is an arena of competition, potentially enabling differing agendas to be reconciled and institutional change to occur (or not) in response to both bottom-up and top-down pressures. How the field of power operates specifically and practically in different cultures, circumstances and jurisdictions, and how the presence of bridging agents influences business decisions within it, are matters for future research.

\section{Acknowledgements}

The authors would like to thank Editor Mike Featherstone, Aeron Davis, Karel Williams, the five anonymous reviewers, and participants at the 'Elite Powers Today' workshop held at Goldsmiths, University of London, in May 2014, for their valuable comments on our paper.

\section{References}

Ahuja, G. (2000) 'Collaboration Networks, Structural Holes and Innovation: A Longitudinal Study’, Administrative Science Quarterly 45(3): 425-455.

Ahuja, G., Soda, G., and Zaheer, A. (2012) 'The Genesis and Dynamics of Organizational Networks', Organization Science 23(2): 434-448.

Anheier, H.K., Gerhards, J., and Romo, F.P. (1995) 'Forms of Capital and Social Structure in Cultural Fields: Examining Bourdieu's Topography', American Journal of Sociology 100(4): 859-903.

Bennett, T., Savage, M., Silva, E., Warde, A., Gayo-Cal, M., and Wright, D. (2009) Culture, Class, Distinction. London: Routledge.

Boltanski, L. and Chiapello, E. (2007) The New Spirit of Capitalism. London: Verso.

Borgatti, S.P., Mehra, A., Brass, D.J. and Labianca, G. (2009) 'Network Analysis in the Social Sciences', Science 323(5916): 892-895.

Bottero, W. (2004) 'Class Identities and the Identity of Class', Sociology 38(5): 9851003.

Bourdieu, P. (1985) 'The Social Space and the Genesis of Groups', Theory and Society 14(6): 723-744. 
This is the version of an article accepted for publication in Theory Culture and Society published by Sage: http://tcs.sagepub.com/

Accepted version downloaded from SOAS Research Online: http://eprints.soas.ac.uk/23092/

Bourdieu, P. (1986) 'The forms of capital'. In Handbook of Theory and Research for the Sociology of Education. J.G. Richardson (ed.), 241-258. New York: Greenwood.

Bourdieu, P. (1986b) Distinction: A Social Critique of the Judgement of Taste. London: Routledge.

Bourdieu, P. (1987) 'What Makes a Social Class? On the Theoretical and Practical Existence of Groups’, Berkeley Journal of Sociology 32: 1-17.

Bourdieu, P. (1990) The Logic of Practice. Cambridge: Polity.

Bourdieu, P. (1993). The Field of Cultural Production. Cambridge: Polity.

Bourdieu, P. (1996a) The State Nobility: Elite Schools in the Field of Power.

Cambridge: Polity.

Bourdieu, P. (1996b) 'Understanding', Theory, Culture \& Society 13(2): 17-37.

Bourdieu, P. (2011) Champ du Pouvoir et Division du Travail de Domination. Actes de la Recherche en Sciences Sociales, 190(5): 126-193.

Bourdieu, P. and Passeron, J-C. (1977) Reproduction in Education, Society and Culture. London : Sage.

Burt, R.S. (1992) Structural Holes : The Social Structure of Competition. Cambridge, MA : Harvard University Press.

Burt, R.S., Hogarth, R.M. and Michaud, C. (2000) 'The Social Capital of French and American Managers', Organization Science 11(2): 123-147.

Carroll, W.K. and Sapinski, J.P. (2011) 'Corporate Elites and Intercorporate Networks', pp. 180-195 in J. Scott, J. and P.J. Carrington (eds) The Sage Handbook of Social Network Analysis. London: Sage Publications.

Coignard, S. and Guichard, M-T. (2000) French Connections. New York: Algora.

Collins-Dogrul, J. (2012) 'Tertius lungens Brokerage and Transnational Intersectoral Cooperation', Organization Studies 33(8): 989-1014.

Courpasson, D. and Clegg, S.R. (2006) 'Dissolving the Iron Cages? Tocqueville, Michels, Bureaucracy and the Perpetuation of Elite Power', Organization 13(3): 319343.

Courpasson, D., Dany, F. and Clegg, S. (2012) 'Resisters at Work: Generating Productive Resistance in the Workplace', Organization Science 23 (3): 801-819.

Creed, W.E.D., Scully, M.A. and Austin, J.R. (2002) 'Clothes Make the Person? The Tailoring of Legitimating Accounts and the Social Construction of Identity', Organization Science 13(5): 475-496. 
This is the version of an article accepted for publication in Theory Culture and Society published by Sage: http://tcs.sagepub.com/

Accepted version downloaded from SOAS Research Online: http://eprints.soas.ac.uk/23092/

Culpepper, P.D. (2008) 'Capitalism, Coordination and Economic Change: the French Political Economy since 1945'. In P.D. Culpepper, P.A. Hall and B. Palier (eds.), Changing France: the Politics that Markets Make. Basingstoke: Palgrave Macmillan, 29-49.

Das, T.K., and Teng, B.-S. (2002). 'Alliance Constellations: A Social Exchange Perspective', Academy of Management Review 27(3): 445-456.

Denord, F., Lagneau-Ymonet, P. and Thine, S. (2011) 'Le Champ du Pouvoir en France', Actes de la Recherche en Sciences Sociales 190: 24-57.

Dezalay, Y. (1995) “Turf battles" or "class struggles": The Internationalization of the Market for Expertise in the "Professional Society", Accounting, Organizations and Society 20(5): 331-344.

Dudouet, F-X. and Joly, H. (2010) 'Les Dirigeants Français du CAC 40: Entre Elitisme Scolaire et Passage par 1'Etat', Sociologies Pratiques 21(2): 35-46.

Ekman, S. (2013) 'Fantasies About Work as Limitless Potential - How Managers and Employees Seduce Each Other Through Dynamics of Mutual Recognition', Human Relations 66(9): 1159-1181.

Eymeri, J.-M. (2001) La Fabrique des Énarques. Paris: Economica.

Flemmen, M. (2012) 'The Structure of the Upper Class: A Social Space Approach', Sociology 46(6): 1039-1058.

Fligstein, N. (1997) 'Social Skill and Institutional Theory', American Behavioral Scientist 40(4): 397-405.

Geletkanycz, M.A. and Hambrick, D.C. (1997) 'The External Ties of Top Executives: Implications for Strategic Choice and Performance', Administrative Science Quarterly 42(4): 654-681.

Genieys, W. (2005) 'The Sociology of Political Elites in France: The End of an Exception?', International Political Science Review 26(4): 413-430.

Giddens, A. (1984) The Constitution of Society. Cambridge: Polity.

Giddens, A. (1991) The Consequences of Modernity. Cambridge: Polity.

Godechot, O. (2011) 'Finance and the Rise of Inequalities in France', Working Paper 13. Paris School of Economics.

Goyer, M. and Jung, D.K. (2011) 'Diversity of Institutional Investors and Foreign Blockholdings in France: The Evolution of an Institutionally Hybrid Economy', Corporate Governance: An International Review 19(6): 562-584. 
This is the version of an article accepted for publication in Theory Culture and Society published by Sage: http://tcs.sagepub.com/

Accepted version downloaded from SOAS Research Online: http://eprints.soas.ac.uk/23092/

Hall, P.A. (1984) Governing the Economy: the Politics of State Intervention in Britain and France. Cambridge: Polity.

Hall, P.A. (2008) 'Introduction: the Politics of Social Change in France'. In P.D. Culpepper, P.A. Hall and B. Palier (eds.), Changing France: the Politics that Markets Make. Basingstoke: Palgrave Macmillan, 1-26.

Halsey, A.H. (1995) Change in British Society, $4^{\text {th }}$ edn. Oxford: OUP.

Hancké, B. (2002) Large Firms and Institutional Change: Industrial Renewal and Economic Restructuring in France. Oxford: OUP.

Hartmann, M. (2000) 'Class-specific Habitus and the Social Reproduction of the Business Elite in Germany and France', The Sociological Review 42 (2): 241-261.

Hartmann, M. (2011) 'Internationalisation et Spécificités Nationales des Elites Economiques', Actes de la Recherche en Sciences Sociales 190(5): 10-23.

Harvey, C. and Maclean, M. (2008) 'Capital Theory and the Dynamics of Elite Business Networking in Britain and France', The Sociological Review 56 (s1): 103120.

Harvey, C. and Maclean, M. (2010) 'Transnational Boards and Governance Regimes in Britain and France'. In M-L. Djelic and S. Quack, eds, Transnational

Communities: Shaping Global Economic Governance, Cambridge: CUP, 107-129.

Harvey, C., Maclean, M., Gordon, J. and Shaw, E. (2011) 'Andrew Carnegie and the Foundations of Contemporary Entrepreneurial Philanthropy', Business History 53(3): 425-450.

Hermskerk, E.M. (2007) Decline of the Corporate Network: Network Dynamics of the Dutch Business Elite. Amsterdam: Amsterdam University Press.

Jessop, B. (2007) State Power. Cambridge: Polity.

Kadushin, C. (1995) 'Friendship among the French Financial Elite', American Sociological Review 60(2): 202-221.

Kerr, R. and Robinson, S. (2011) 'Leadership as an Elite Field: Scottish Banking Leaders and the Crisis of 2007-2009', Leadership 7(2): 151-173.

Khan, S.R. (2011) Privilege: The Making of an Adolescent Elite at St Paul's School. Princeton: Princeton University Press.

Kling, G., Harvey, C. and Maclean, M. (2016) 'Establishing Causal Order in Longitudinal Studies Combining Binary and Continuous Dependent Variables', Organizational Research Methods 19, forthcoming.

Korn/Ferry International (2002) Gouvernement d'entreprise en France en 2002, Paris. 
This is the version of an article accepted for publication in Theory Culture and Society published by Sage: http://tcs.sagepub.com/

Accepted version downloaded from SOAS Research Online: http://eprints.soas.ac.uk/23092/

Le Wita, B. (1994) French Bourgeois Culture. Cambridge: CUP.

Lindsay, D.M. (2008) 'Evangelicals in the Power Elite: Elite Cohesion Advancing a Movement', American Sociological Review 73(1): 60-82.

Lounsbury, M. and Glynn, M.A. (2001) 'Cultural Entrepreneurship: Stories, Legitimacy, and the Acquisition of Resources', Strategic Management Journal 22(67): 545-564.

Maclean, M. (2002) Economic Management and French Business from de Gaulle to Chirac. Basingstoke: Palgrave Macmillan.

Maclean, M. and Harvey, C. (2016) "“Give it Back, George": Network Dynamics in the Philanthropic Field', Organization Studies 37(3): 399-423.

Maclean, M., Harvey, C. and Chia, R. (2010) 'Dominant Corporate Agents and the Power Elite in France and Britain’, Organization Studies 31(3): 327-348.

Maclean, M., Harvey, C. and Chia, R. (2012) 'Reflexive Practice and the Making of Elite Business Careers', Management Learning 43(4): 385-404.

Maclean, M., Harvey, C. and Kling, G. (2014) 'Pathways to Power: Class, Hyperagency and the French Corporate Elite', Organization Studies 35(6): 825-855.

Maclean, M., Harvey, C. and Kling, G. (2015) 'Business Elites and the Field of Power in France', Research in the Sociology of Organizations 43: 189-219.

Maclean, M., Harvey, C. and Press, J. (2006) Business Elites and Corporate Governance in France and the UK. Basingstoke: Palgrave Macmillan.

Maclean, M., Harvey, C. and Press, J. (2007) 'Managerialism and the Post-war Evolution of the French National Business System', Business History 49(4): 531-551.

McDonald, M.L., Khanna, P. and Westphal, J.D. (2008) 'Getting Them to Think Outside the Circle: Corporate Governance, CEO's External Advice Networks, and Firm Performance', Academy of Management Journal 51(3): 453-475.

Mills, C.W. (1956) The Power Elite. Oxford: OUP.

Mizruchi, M.S. (1986) 'What do interlocks do? An Analysis, Critique, and Assessment of Research on Interlocking Directorates', Annual Review of Sociology 22: 271-298.

Morin, F. (2000) 'A Transformation in the French Model of Shareholding and Management', Economy and Society 29(1): 36-53.

Moulin, Y. and Point, S. (2013) 'Les Administratrices des Grands Groupes Français Cotés: Quels Atouts Privilégier?’, Revue Française de Gestion 233(4): 15-32. 
This is the version of an article accepted for publication in Theory Culture and Society published by Sage: http://tcs.sagepub.com/

Accepted version downloaded from SOAS Research Online: http://eprints.soas.ac.uk/23092/

North, D.C. (1990) Institutions, Institutional Change and Economic Performance. Cambridge: Cambridge University Press.

O’Mahony, S. and Bechky, B.A. (2008) 'Boundary Organizations: Enabling Collaboration among Unexpected Allies', Administrative Science Quarterly 53(3): 422-459.

Palmer, D. and Barber, B.M. (2001) 'Challengers, Elites, and Owning Families: A Social Class Theory of Corporate Acquisitions in the 1960s', Administrative Science Quarterly 46(1): 87-120.

Piketty, T. (2014) Capital in the Twenty-First Century. Belknap: Cambridge, MA.

Pinçon, M. and Pinçon-Charlot, M. (2007) Sociologie de la Bourgeoisie. Paris: La Découverte.

Reed, M.I. (2012) 'Masters of the Universe: Power and Elites in Organization Studies', Organization Studies 33(2): 203-221.

Robson, K. and Sanders, C. (Eds) (2009) Quantifying Theory: Pierre Bourdieu. New York: Springer.

Savage, M. (2000) Class Analysis and Social Transformation. Milton Keynes: Open University.

Savage, M., Cunningham, N., Devine, F., Friedman, S., Laurison, D., McKenzie, L., Miles, A., Snee, H. and Wakeling, P. (2015) Social Class in the $21^{\text {st }}$ Century. Harmondsworth: Penguin.

Savage, M., Warde, A. and Devine, F. (2005) 'Capitals, Assets, and Resources: Some Critical Issues’, British Journal of Sociology 56(1): 31-47.

Savage, M. and Williams, K. (2008) 'Elites: Remembered in Capitalism and Forgotten by Social Sciences', The Sociological Review, 56(s1), 1-24.

Scott, J. (1991) 'Networks of Corporate Power: A Comparative Assessment', Annual Review of Sociology, 17: 181-203.

Scott, J. (2002) 'Social Class and Stratification in Late Modernity', Acta Sociologica, 45(1): 23-35.

Stern, I. and Westphal, J.D. (2010) 'Stealthy Footsteps to the Boardroom: Executives' Backgrounds, Sophisticated Interpersonal Influence Behaviour, and Board Appointments', Administrative Science Quarterly 55(2): 278-319.

Stevenson, W.B. and Radin, R.F. (2009) 'Social Capital and Social Influence on the Board of Directors', Journal of Management Studies 46(1): 16-44.

Suleiman, E. (1978) Elites in French Society. Princeton: Princeton University Press. 
This is the version of an article accepted for publication in Theory Culture and Society published by Sage: http://tcs.sagepub.com/

Accepted version downloaded from SOAS Research Online: http://eprints.soas.ac.uk/23092/

Swartz, D.L. (1997) Culture and Power: The Sociology of Pierre Bourdieu. London. University of Chicago Press.

Swartz, D.L. (2008) 'Bringing Bourdieu's Master Concepts into Organizational Analysis', Theory and Society 37(1): 45-52.

Useem, M. (1984) The Inner Circle: Large Corporations and the Rise of Business Political Activity in the US and UK. Oxford: OUP.

Useem, M. and Karabel, J. (1986) 'Pathways to Top Corporate Management', American Sociological Review 51(2): 184-200.

Wacquant, L.J.D. (1993) 'From Ruling Class to Field of Power: An Interview with Pierre Bourdieu on La Noblesse d'état', Theory, Culture and Society 10(3): 19-44.

Wacquant, L.J.D. (2002) 'The Sociological Life of Pierre Bourdieu', International Sociology 17(4): 549-556.

Westphal, J.D. and Zajac, E.J. (1995) 'Who Shall Govern? CEO/Board Power, Demographic Similarity, and New Director Selection', Administrative Science Quarterly 40(1): 60-83.

Zajac, E.J. and Westphal, J.D. (1996) 'Director Reputation, CEO-Board Power, and the Dynamics of Board Interlocks', Administrative Science Quarterly 41(3): 507-529.

Zald, M.N. and Lounsbury, M. (2010) 'The Wizards of Oz: Towards an Institutional Approach to Elites, Expertise and Command Posts', Organization Studies 31(7): 963 996.

Zaheer, A., Gözübüyük, R., and Milanova, H. (2010) 'It's the Connections: The Network Perspective in Interorganizational Research', Academy of Management Perspectives 24(1), 62-77. 
This is the version of an article accepted for publication in Theory Culture and Society published by Sage: http://tcs.sagepub.com/

Accepted version downloaded from SOAS Research Online: http://eprints.soas.ac.uk/23092/

Figure 1: Bridging actor 429

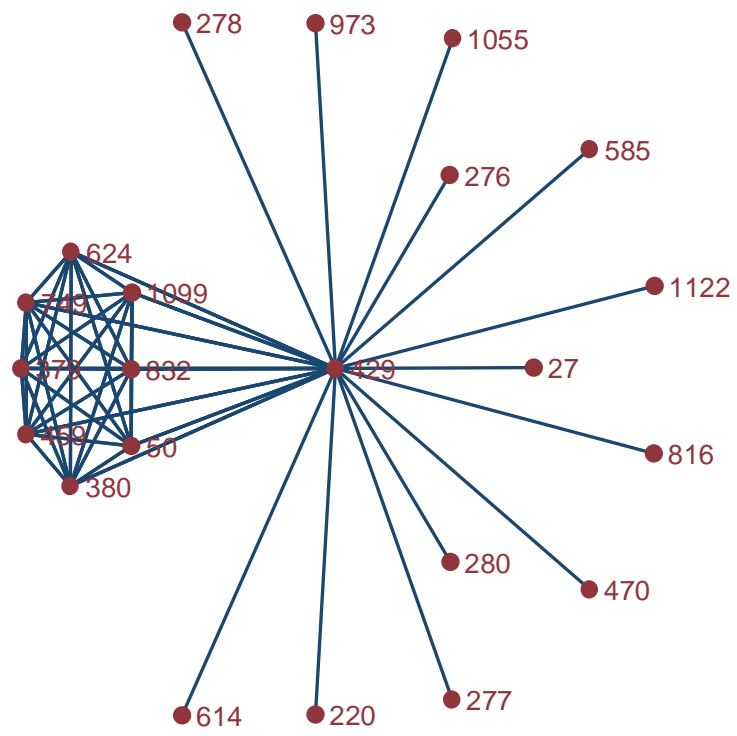


This is the version of an article accepted for publication in Theory Culture and Society published by Sage: http://tcs.sagepub.com/

Accepted version downloaded from SOAS Research Online: http://eprints.soas.ac.uk/23092/

Table 1: Summary Statistics

\begin{tabular}{lrrrrr}
\hline Variable & Obs & Mean & Std & Min & Max \\
\hline SIZE & 1068 & 10.55 & 7.36 & 1.00 & 77.00 \\
ST & 1068 & 0.02 & 0.08 & 0.00 & 0.63 \\
MAX_ST & 1068 & 0.01 & 0.02 & 0.00 & 0.23 \\
STRONG & 1082 & 0.08 & 0.27 & 0.00 & 1.00 \\
BRIDGE & 1082 & 0.21 & 0.41 & 0.00 & 1.00 \\
GENDER & 1082 & 0.95 & 0.21 & 0.00 & 1.00 \\
AGE & 1082 & 55.39 & 9.66 & 20.00 & 92.00 \\
NATION & 1081 & 0.94 & 0.25 & 0.00 & 1.00 \\
PARIS & 1082 & 0.33 & 0.47 & 0.00 & 1.00 \\
ES & 923 & 0.56 & 0.50 & 0.00 & 1.00 \\
EHE & 1048 & 0.78 & 0.41 & 0.00 & 1.00 \\
EXNET & 1082 & 1.47 & 1.19 & 0.00 & 5.00 \\
C_1 & 1082 & 0.20 & 0.40 & 0.00 & 1.00 \\
C_2 & 1082 & 0.43 & 0.50 & 0.00 & 1.00 \\
C_3 & 1082 & 0.32 & 0.47 & 0.00 & 1.00 \\
C_4 & 1082 & 0.05 & 0.22 & 0.00 & 1.00 \\
\hline
\end{tabular}

Note $:$ Obs $=$ number of observations. Std $=$ standard deviation. Min $=$ minimum value. Max = maximum value. The dependent variables refer to the number of connections (SIZE), average eigenvector centrality (ST), maximum eigenvector centrality (MAX_ST) and the dummy STRONG, which takes the value one for a strictly positive eigenvector centrality or zero otherwise. The dummy BRIDGE for bridging actors is treated as an independent and dependent variable to explore direct and indirect effects of social class. The independent variables are for gender, age, nationality, place of upbringing, elite education (ES, EHE), the number of extracorporate networks (EXNET) and social class (C_1, C_2, C_3, C_4). 
This is the version of an article accepted for publication in Theory Culture and Society published by Sage:

http://tcs.sagepub.com/

Accepted version downloaded from SOAS Research Online: http://eprints.soas.ac.uk/23092/

Table 2: Descriptive statistics

\begin{tabular}{llllllll}
\hline \multicolumn{7}{l}{ Panel A: Bridging agents (1) versus non-bridging agent (0) } \\
\hline 0 & AGE & ES & EHE & C_1 & C_2 & C_3 & C_4 \\
\hline 1 & 55.17 & 0.52 & 0.75 & 0.20 & 0.40 & 0.34 & 0.06 \\
ALL & 56.19 & 0.69 & 0.89 & 0.21 & 0.52 & 0.24 & 0.03 \\
\hline
\end{tabular}

Panel B: Number of life-worlds spanned (1,2,3 or 4)

\begin{tabular}{llllllll}
\hline & AGE & ES & EHE & C_1 & C_2 & C_3 & C_4 \\
\hline 1 & 54.70 & 0.30 & 0.61 & 0.10 & 0.28 & 0.54 & 0.08 \\
2 & 54.29 & 0.47 & 0.72 & 0.01 & 0.39 & 0.50 & 0.10 \\
3 & 55.64 & 0.64 & 0.82 & 0.28 & 0.47 & 0.21 & 0.03 \\
4 & 56.28 & 0.72 & 0.90 & 0.32 & 0.51 & 0.14 & 0.03 \\
ALL & 55.39 & 0.56 & 0.78 & 0.20 & 0.43 & 0.32 & 0.05 \\
\hline
\end{tabular}

Panel C: Extra-corporate networks $(0,1,2$ or 3$)$

\begin{tabular}{llllllll}
\hline & AGE & ES & EHE & C_1 & C_2 & C_3 & C_4 \\
\hline 0 & 54.59 & 0.36 & 0.62 & 0.08 & 0.31 & 0.54 & 0.08 \\
1 & 53.35 & 0.49 & 0.76 & 0.08 & 0.42 & 0.41 & 0.08 \\
2 & 55.39 & 0.71 & 0.87 & 0.35 & 0.50 & 0.14 & 0.02 \\
3 & 58.80 & 0.71 & 0.90 & 0.29 & 0.50 & 0.18 & 0.03 \\
ALL & 55.39 & 0.56 & 0.78 & 0.20 & 0.43 & 0.32 & 0.05 \\
\hline
\end{tabular}

Note: The sample is divided by actor status (Panel A), life-worlds spanned (Panel B) and number of extra-corporate networks (Panel C). Each panel provides a crosstabulation by age, elite education, and social class. 
This is the version of an article accepted for publication in Theory Culture and Society published by Sage: http://tcs.sagepub.com/

Accepted version downloaded from SOAS Research Online: http://eprints.soas.ac.uk/23092/

Table 3: Direct effect of class, education and external networks

\begin{tabular}{lllll}
\hline & $\mathrm{A}$ & $\mathrm{B}$ & $\mathrm{C}$ & $\mathrm{D}$ \\
\hline BRIDGE & $0.922 * * *$ & $0.206^{* *}$ & $0.054 * *$ & 0.412 \\
GENDER & 0.013 & 0.314 & 0.088 & - \\
AGE & -0.001 & -0.003 & -0.001 & -0.008 \\
NATION & -0.015 & -0.214 & -0.057 & -0.002 \\
PARIS & 0.024 & $0.164 *$ & $0.041^{*}$ & 0.556 \\
ES & $0.094 * *$ & - & - & 0.449 \\
EHE & $0.114 * *$ & 0.148 & 0.035 & 0.225 \\
EXNET & $0.046^{* * *}$ & 0.054 & 0.015 & 0.180 \\
C_1 & -0.131 & -0.067 & -0.012 & 0.134 \\
C_2 & -0.077 & -0.084 & -0.019 & -0.110 \\
C_3 & -0.003 & -0.028 & -0.003 & 0.249 \\
Constant & $2.572 * * *$ & $-1.064 * *$ & $-0.292^{* *}$ & $-3.207 *$ \\
\hline N & 913 & 1034 & 1034 & 890 \\
aic & 910.594 & 458.809 & 272.73 & 493.156 \\
bic & 968.395 & 518.103 & 332.024 & 545.86 \\
R-squared & 0.535 & 0.059 & 0.100 & 0.039 \\
\hline
\end{tabular}

Note: Model A explains the size of networks (SIZE) using an OLS regression. As SIZE is not normally distributed, we use a log transformation for the dependent variable. Models B and C refer to tobit models explaining the average (ST) and maximum eigenvector centrality (MAX_ST) respectively. In models B and C, the explanatory variable ES needs to be dropped to avoid non-convergence due to restricting the number of observations. Model D uses a logistic regression to explain the dummy STRONG. The dummy GENDER drops from Model D due to perfect predictability. All models are estimated using robust standard errors to account for heteroskedasticity. 
This is the version of an article accepted for publication in Theory Culture and Society published by Sage: http://tcs.sagepub.com/

Accepted version downloaded from SOAS Research Online: http://eprints.soas.ac.uk/23092/

Table 4: Indirect effect of social class

\begin{tabular}{llllll}
\hline & $\mathrm{E}$ & $\mathrm{F}$ & $\mathrm{G}$ & $\mathrm{H}$ & $\mathrm{I}$ \\
\hline GENDER & $0.342^{*}$ & $1.802 * * *$ & 0.486 & 0.090 & -0.174 \\
AGE & $0.018^{* * *}$ & -0.002 & 0.000 & 0.013 & $0.019 *$ \\
NATION & $-0.802^{* * *}$ & -0.685 & -0.450 & 0.091 & 0.070 \\
PARIS & -0.005 & $0.930^{* * *}$ & $1.450^{* * *}$ & $0.417 * *$ & 0.246 \\
C_1 & $1.076^{* * *}$ & $3.163 * * *$ & $1.949 * * *$ & 0.875 & 0.738 \\
C_2 & $0.746^{* * *}$ & $2.557 * * *$ & $2.347 * * *$ & $1.035^{*}$ & 0.632 \\
C_3 & 0.020 & 0.249 & 0.458 & 0.469 & 0.458 \\
ES & - & - & - & - & 0.333 \\
EHE & - & - & - & - & $0.584 *$ \\
Constant & 0.354 & $-2.760 * *$ & -0.363 & $-3.162 * * *$ & $-3.514 * * *$ \\
\hline N & 1081 & 923 & 1047 & 1081 & 922 \\
aic & 3221.01 & 953.277 & 910.909 & 1105.86 & 983.928 \\
bic & 3260.9 & 991.898 & 950.538 & 1145.74 & 1032.19 \\
R-squared & 0.190 & 0.260 & 0.183 & 0.024 & 0.035 \\
\hline
\end{tabular}

Note: Model E uses an OLS regression to explain the number of extra-corporate networks. Models F, G and $\mathrm{H}$ apply logistic regressions with the binary variables elite schooling (ES), elite higher education (EHE) and bridging actor (BRIDGE) as dependent variables. Model I extends Model $\mathrm{H}$ by incorporating the impact of elite education. All models are estimated using robust standard errors to account for heteroskedasticity. 